УДК 37.064.3:373.5

DOI: https://doi.org/10.35619/iiu.v0i9.137

Oleksandr Fedoryshyn

Candidate of Pedagogical Sciences, Associate Professor, Associate Professor at Practice of the English Language Department,

Rivne State University of the Humanities

Rivne, Ukraine

ORCID: 0000-0003-0731-0186

e-mail: ofedoryshin@gmail.com

\title{
BULLYING OR CONFLICT? BULLY-PROOFING STRATEGIES FOR PREVENTION AND INTERVENTION IN CANADIAN SCHOOLS
}

\begin{abstract}
The article focuses on school bullying, which is rather spread in different countries of the world and is considered to be actual social and pedagogical and psychological problem nowadays. Being serious and massive phenomenon bullying needs solving, from clear definition of the notion to working-outs of practical recommendations for its prophylaxis and neutralization. In the article definitions and characteristics of forms and variants of school bullying development, which constantly are changing, adopting to certain circumstances; for example, the development of such new modern variant of aggression as cyberbullying are given.

Bullying happens at all ages, in all countries, between children, teenagers and grown-ups. It happens mostly between the ages of 10-14. No form of bullying should be tolerated. Bullying in schools must be dealt with as a serious issue; it is not a normal behaviour and it can bring serious damage to the further development of the individuals being aggressed.

To increase the level of this negative social phenomenon the experience of Canada in antibullying measures can be taken into consideration. The bullying problem is very actual in Canadian schools. Schools of Canada are aimed at more constructive principles of preventive character in bullying overcoming and neutralization. Anti-bullying work has harmonious mechanism and means school cooperation with students and their parents, public organizations, members of community and is supported by government institutions.

Studies have shown that a higher percentage of children engaged in bullying behaviour is in middle school and high school than in elementary school. But, the percentages of children victimized gradually decreases with age.

Key words: school bullying, cyberbullying, bully, victim, bystander bullying behaviour, bullying prevention and intervention, aggression, anti-bullying legislation.

Formulation of the problem. Every child has the right to feel safe at home, at school and in the community (UN Convention on the Rights of the Child, 1990). Bullying is not a normal part of growing up. Research indicates that bullying behaviour doesn't usually go away on its own and often gets worse with time - it needs to be dealt with directly. To stop the hurtful behaviour, adults need to support children who see their help. They need to respond immediately and take preventative steps to stop the behaviour from happening in the future. The first step is recognizing when a bullying problem has occurred.

During the early twenty-first century, school bullying emerged as a social problem of epidemic proportions within academic, news media and public discourse.
\end{abstract}


Bullying has been linked to other social problems. Scientists identify how this discourse has expanded the conceptualization and domain of school bullying and has stirred public hysteria.

School bullying is a type of bullying that occurs in any educational setting. Bullying is the use of force, threat, or coercion to abuse, intimidate or aggressively dominate others. The behaviour is often repeated and habitual. One essential prerequisite is the perception, by the bully or by others, of an imbalance of social or physical power, which distinguishes bullying from conflict (Juvonen \& Graham, 2014, p. 161).

Bullying can have a wide spectrum of effects on a student including anger, depression, stress and suicide. Additionally, the bully can develop different social disorders or have a higher chance of engaging in criminal activity. If there is suspicion that a child is being bullied or is a bully, there are warning signs in their behaviour. There are many programs and organizations worldwide which provide bullying prevention services or information on how children can cope if they have been bullied.

There is no universal definition of school bullying; however, it is widely agreed that bullying is a subcategory of aggressive behaviour characterized by the following three minimum criteria (Burger \& et al., 2015, p. 195):

- hostile intent (i.e., the harm caused by bullying is deliberate, not accidental);

- imbalance of power (i.e., bullying includes a real or perceived power inequity between the bully and the victim);

- repetition over a period of time (i.e., more than once with the potential to occur multiple times) (Craig \& Pepler, 1997).

The following two additional criteria have been proposed to complement the above-mentioned criteria:

- victim distress (victim suffers mild to severe psychological, social or physical trauma) (Craig \& Pepler, 1997) and

- provocation (bullying is motivated by perceived benefits of their power imbalance: bullies and victims often report that conflicts occur between two equals); nevertheless, they remain widely established in the scientific literature (Juvonen \& Graham, 2014).

Bullying includes assault, tripping, intimidation, rumour-spreading and isolation, demands for money, destruction of property, theft of valued possessions, destruction of another's work, and name-calling. But not all taunting, teasing and fighting among schoolchildren constitutes bullying (Olweus, 1993). Two persons of approximately the same strength (physical or psychological) "fighting or quarrelling" is not bullying. Rather, bullying entails repeated acts by someone perceived as physically or psychologically more powerful.

Extensive studies in other countries during the 1980s and 1990s generally found that between 8 and 38 percent of students are bullied with some regularity, and that between five and nine percent of students bully others with some regularity. Chronic victims of bullying, bullied once a week or more, generally constitute between 8 and 20 percent of the student population. Most students do not report bullying to adults. Surveys from a variety of countries confirm that many victims and witnesses fail to tell teachers or even parents.

International research suggests that bullying is common at schools and occurs beyond elementary school; bullying occurs at all grade levels, although most 
frequently during elementary school. It occurs slightly less often in middle schools, and less so, but still frequently, in high schools. High school freshmen are particularly vulnerable.

Dan Olweus, a researcher in Norway, conducted groundbreaking research in the 1970s exposing the widespread nature and harm of school bullying (Olweus, 1978).

Bullying is well documented in Europe, Canada, Japan, Australia, and New Zealand, providing an extensive body of information on the problem. Research from some countries has shown that, without intervention, bullies are much more likely to develop a criminal record than their peers, and bullying victims suffer psychological harm long after the bullying stops. As young adults, former school bullies in Norway had a fourfold increase in the level of relatively serious, recidivist criminality (Olweus, 1993). Dutch and Australian studies also found increased levels of criminal behaviour by adults who had been bullies (Farrington, 1993).

Many of the European and Scandinavian studies concur that bullies tend to be aggressive, dominant and slightly below average in intelligence and reading ability (by middle school), and most evidence suggests that bullies are at least of average popularity (Farrington, 1993). In Australia, research shows that bullies have low empathy levels, are generally uncooperative and, based on self-reports, come from dysfunctional families low on love. Their parents tend to frequently criticize them and strictly control them. Dutch (and other) researchers have found a correlation between harsh physical punishments such as beatings, strict disciplinarian parents and bullying. In U.S. studies, researchers have found higher bullying rates among boys whose parents use physical punishment or violence against them. Some researchers suggest that bullies have poor social skills and compensate by bullying. Others suggest that bullies have keen insight into others' mental states and take advantage of that by picking on the emotionally less resilient (Steven, De Bourdeandhuij, Van Oost, 2000). A number of researchers believe that bullying occurs due to a combination of social interactions with parents, peers and teachers (Olweus, 1992).

Therefore, the aim of the article is to demonstrate and summarize the experience of Canada in bullying prevention and neutralization at secondary schools.

Presenting the main research material. Not surprisingly, the definition of bullying has evolved over time as research has revealed that other types of nonphysical behaviour can have similar impacts on the victim. The damaging effects of psychological and verbal bullying as well as social exclusion are now being recognized, although not everyone incorporates these behaviours into their definition or their action plans.

According to Public Safety Canada, bullying is "characterized by acts of intentional harm, repeated over-time, in a relationship where an imbalance of power exists. It includes physical actions (punching, kicking, biting), verbal actions (threats, name calling, insults, racial or sexual comments), and social exclusion (spreading rumours, ignoring, gossiping, excluding)." Notably, a 2010 report for the Public Health Agency of Canada, on the Health of Canada's Young People, found approximately $40 \%$ of adolescents to be both bullies and victims of bullying. And for all concerned, whether victim, bully, or both, the consequences can be many and long-lasting (Bullying Policy \& Legislation).

For those engaged in bullying, there may also be legal repercussions. While there is no offense termed bullying under the Canadian Criminal Code per se, many 
behaviours or incidents characterized as bullying fit the definition of criminal offenses. These include, for example, Criminal Harassment (CCC 264), Uttering Threats (CCC 264.1), Assault (CCC 265 \& 266), and Sexual Assault (CCC 271), with perpetrators risking youth or adult sentencing depending on the circumstances of the crime(s). For more on this topic, see the John Howard Society for an accessible look at bullying and the law.

The definition of bullying is broad based, encompassing a wide range of behaviours within a personal relationship. Bullying includes actions within a relationship between a dominant and a less dominant person or group (see Chart 1) where:

- An imbalance of power (real or perceived) is manifest through aggressive actions, physical or psychological (including verbal or social);

- Negative interactions occur that are direct (face-to-face) or indirect (gossip, exclusion);

- Negative actions are taken with an intention to harm. These can include some or all of the following;

- Physical actions (punching, kicking, biting),

- Verbal actions (threats, name calling, insults, ethnoculturally-based or sexual comments), and

- Social exclusion (spreading rumours, ignoring, gossiping, excluding).

- The negative actions are repeated. Either the intensity or the duration of the actions establishes the bully's dominance over the victim (Bullying Policy \& Legislation).

In recent years cyberbullying has emerged as a significant challenge for schools (particularly secondary schools). It involves the use of communication technologies such as the Internet, social networking sites, websites, email, text messaging and instant messaging to repeatedly intimidate or harass others. One is that while investigating face-to-face bullying relies on eyewitness reports, cyberbullying usually generates hard evidence - a screenshot or printout of a text or Facebook post.

In most cases it is easy to identify the perpetrator. However, many of the apparent cyberbullying cases investigated turn out to be more about conflict than the use of power to oppress a weaker victim.

The other difference between cyberbullying and face-to-face bullying is that engaging the support of parents becomes even more crucial with cyberbullying. Teachers can rely on parents to monitor or restrict technology use when students are involved in cyberbullying or conflict.

Cyberbullying includes:

- Sending mean or threatening emails or text/instant messages.

- Posting embarrassing photos of someone online.

- Creating a website to make fun of others.

- Pretending to be someone by using their name.

- Tricking someone into revealing personal or embarrassing information and sending it to others (Bernstein \& Watson, 1997). 


\begin{tabular}{|c|c|c|}
\hline \multicolumn{3}{|c|}{ Chart 1 - Types and effects of bullying (Bullying prevention in schools) } \\
\hline \multirow{2}{*}{ Physical } & \multicolumn{2}{|c|}{ Psychological } \\
\hline & Verbal & Social \\
\hline $\begin{array}{ll}- & \text { Hitting } \\
\text { - } & \text { Kicking } \\
\text { - } & \text { Punching } \\
\text { - } & \text { Pushing/Shoving } \\
\text { - } & \text { Stealing } \\
\text { - } & \text { Dating Aggression } \\
\text { Footnote } *\end{array}$ & $\begin{array}{l}\text { - Insults } \\
\text { - Name calling } \\
\text { - Comments about how } \\
\text { you look or talk } \\
\text { - Threats } \\
\text { - Sexual Harassment } \\
\text { Footnote ** } \\
\text { - Ethnoculturally-Based } \\
\text { Comments Footnote } * * *\end{array}$ & $\begin{array}{llr}\text { - } & \text { Gossiping } & \\
\text { - } & \text { Rumours } \\
\text { - } & \text { Ignoring } \\
\text { - } & \text { Not } & \\
\text { someone including } \\
\text { activities }\end{array}$ \\
\hline \multicolumn{3}{|c|}{ Results } \\
\hline $\begin{array}{l}\text { Can hurt the young person's } \\
\text { body, damage belongings or } \\
\text { make the person feel badly } \\
\text { about himself or herself. }\end{array}$ & $\begin{array}{l}\text { Can make the young person } \\
\text { feel badly about himself or } \\
\text { herself. }\end{array}$ & $\begin{array}{l}\text { Can make the young } \\
\text { person feel alone and not } \\
\text { part of the group. }\end{array}$ \\
\hline \multicolumn{3}{|c|}{$\begin{array}{l}\text { * Dating aggression - physical or verbal actions including grabbing, pushing or punching, the } \\
\text { spreading of rumours, and name-calling. } \\
\text { ** Sexual harassment - occurs when a person or group hurts another person by taunting or } \\
\text { discussing sensitive sexual issues, creating sexual rumours or messages, making homophobic } \\
\text { comments, rating sexual body parts or name-calling, telling sexual jokes, and initiating } \\
\text { unwanted sexual touching. } \\
\text { *** Ethnoculturally-based bullying - any physical or verbal behaviour used to hurt another } \\
\text { person because of his or her ethnocultural background. }\end{array}$} \\
\hline
\end{tabular}

Cyberbullying affects victims in different ways than traditional bullying. It can follow a victim everywhere 24 hours a day, 7 days a week, from school, to the mall and all the way into the comfort of their home - usually safe from traditional forms of bullying. In Canada even a special police site https://www.cybertip.ca/ has been formed and any witness or victim can address their complaints about bullying. The Government of Canada and the Royal Canadian Mounted Police are committed to providing websites that respect the privacy of visitors. This privacy notice summarizes the privacy practices for the Royal Canadian Mounted Police's online activities. All personal information collected by this institution is governed by the Privacy Act. This means that you will be informed of the purpose for which your personal information is being collected and how to exercise your right of access to that information. In 2015, the criminal code was updated to include a new offence to share intimate images of a person without consent.

Bullying situations usually involve more than the bully and the victim. They also involve bystanders - those who watch bullying happen or hear about it. An important new strategy for bullying prevention focuses on the powerful role of the bystander. Depending on how bystanders respond, they can either contribute to the problem or the solution. Bystanders rarely play a completely neutral role, although they may think they do.

Bystanders may be divided into two categories: hurtful bystanders and helpful bystanders. Hurtful bystanders are those who instigate the bullying by prodding the bully to begin; encourage the bullying by laughing, cheering, or making comments that further stimulate the bully; join in the bullying once it has begun; passively accept bullying by watching and doing nothing. Often without realizing it, these bystanders also contribute to the problem. Passive bystanders provide the audience a 
bully craves and the silent acceptance that allows bullies to continue their hurtful behaviour. Helpful bystanders also have the power to play a key role in preventing or stopping bullying. Some directly intervene, by discouraging the bully, defending the victim, or redirecting the situation away from bullying. Other bystanders get help, by rallying support from peers to stand up against bullying or by reporting the bullying to adults (Bystanders Eyes on Bullying).

All children can be empowered to become helpful bystanders. Adults can prepare to become such by discussing with them the different ways bystanders can make a difference, and by letting them know that adults will support them, if and when they step forward. Adults can also provide examples of how helpful bystanders have shown courage and made a difference in real-life situations and in their own experiences. Adults need to pay special attention to children who are most at risk. Bullies are especially attracted to passive victims who react by crying or running away or who seem to lack self-confidence. But anyone can be a target (Carach, Pepler \& Ziegler, 2005, p. 15).

Bullies, victims and bystanders all play important role in contributing to bullying - and each can help make bullying stop. More than one-half the time, bullying stops within 10 seconds of a bystander stepping in to help.

Canadian researchers began collecting data in the early 1990s to determine the prevalence of bullying in Canadian schools. These studies generally concluded that Canadian students, like students in other countries around the world, suffer from bullying at school at rates and frequencies that cannot be ignored. In fact, a study conducted by the World Health Organization, which surveyed the health behaviours of school aged children around the world, found that Canada ranked in the middle of 35 countries studied for level of bullying. Other Canadian studies have identified bullying and victimization rates and the impact on these rates of peers and adults. Most Canadians believe bullying is a serious problem among students. Increased awareness and media coverage has created country-wide interest in addressing this problem. Bullying is no longer considered "just part of growing up" but is now being described by some as an epidemic.

Educators share responsibility with parents and other adults in students' lives. All school staff who work directly with students have an obligation to respond to and report incidents that can have a negative impact on the school climate. This includes principals and vice principals, teachers, educational assistants and all other staff employed by the school board, such as those involved in social work, child and youth work, psychology and other related disciplines. The Ministry of Education is expected to develop a model bullying and cyberbullying prevention and intervention plan to assist individual school boards in establishing their own bullying and cyberbullying prevention and intervention activities and to make information about the number of reported suspensions and expulsions with respect to bullying and cyberbullying incidents available to parents/guardians (Bullying \& Cyberbullying, 2017).

Bullying as a big problem makes Canadians often look to government to solve large challenges. Canadian policymakers are very motivated to legislate on the bullying issue. Provincial politicians across the country are proposing anti-bullying bills or promising forthcoming legislation. 2012 will be known as the year antibullying legislation swept across Canada.

In Manitoba, Bill 18, which came into effect on April 15, 2012, amended The Public Schools Act specific to bullying and respect for human diversity. The term 
'bullying' is defined, and school boards of publicly-funded non-religious and religious schools must both expand their policies about the appropriate use of the Internet and establish a respect for human diversity policy.

In Nova Scotia, Bill 30, the Promotion of Respectful and Responsible Relationships Act was introduced in April and received assent on May 17, 2012 shortly after the release of a task force report on bullying. The new Act resulted in bullying and cyberbullying being specifically addressed in the Education Act and the creation of a provincial school code of conduct. Bullying was further addressed on April 25, 2013 with the introduction of Bill 61, Cyber-safety Act to further address cyberbullying in particular.

New Brunswick's Education Act was amended to address bullying and cyberbullying via Bill 45 on June 13, 2012. With an emphasis on "prevention, reporting, investigating and taking action," bullying and cyberbullying were highlighted; the roles and responsibilities of principals, educators, parents, students and parent school support committees were clarified, along with protocols for discipline and intervention; and increased reporting at various levels was mandated.

On June 15, 2012, Bill 56 received assented in Quebec, amending the Education Act and the Act Respecting Private Education in relation to bullying and violence. Through these amendments, terms and responsibilities were defined, including the obligation of all public and private educational institutions to adopt and implement an anti-bullying and anti-violence plan.

Shortly thereafter, Ontario's Education Act was amended on June 19, 2012 by Bill 13 with respect to bullying and other matters. New legal obligations exist for school boards and schools to prevent bullying; tougher consequences will be meted out for bullying; and students wanting to promote understanding and respect for all will be more so supported.

In Alberta, bullying is taken up in the Education Act, which received Royal Assent on December 10, 2012, and is specifically addressed by Bill 3. The term 'bullying' is defined; school boards will be required to establish a student code of conduct; and the National Bullying Awareness Week will be formalized as Bullying Awareness and Prevention Week.

Of the remaining provinces and territories, most have strategies in place to address bullying, and some have even tabled motions to consider anti-bullying legislation, too. In January 2008, Yukon passed the Safe and Caring Schools Policy, in which bullying in defined and clarification is provided around roles and responsibilities, standards and policies. British Columbia introduced ERASE Bullying (Expect Respect and a Safe Education) - a prevention and intervention strategy building on the province's Safe, Caring and Orderly Schools Strategy - in June 2012. Saskatchewan announced an anti-bullying strategy in February 2005, which ties into the province's Caring and Respectful Schools initiative. A year later, in May 2006, Newfoundland and Labrador established a provincial Safe and Caring Schools Policy. Nunavut, though, has neither legislation nor a broad strategy in place specific to bullying.

Finally, Prince Edward Island is presently considering legislation, just over a year after a motion was passed in April 2012 to encourage government in the adoption of anti-bullying legislation. Shortly thereafter, the Northwest Territories also passed a motion, in June 2012, recommending the establishment of a territorywide anti-bullying campaign and the review of anti-bullying legislation across 
Canada (An Overview of Anti-bullying Legislation and Alternatives in Canada, 2013).

Following the increased occurrence of bullying in schools among Canadian youths aged 11 to 16, and high-profile suicides of young persons due to bullying, several jurisdictions in Canada are in the process of enacting antibullying laws. The aim of the laws is to make educational institutions safer by bringing awareness of the issue and consequences of bullying, and promoting tolerance in all public schools.

On a provincial level, a number of different approaches have been taken. At present, only some of the provinces have anti-bullying legislation in place, with mixed opinions as to their efficacy, while the other provinces and territories have opted to address bullying in different ways. What follows are recent legislative changes specific to bullying, as well as a quick look at the approaches taken by the others.

The Canadian provinces have taken their own measures to curb bullying (Chart 2).

\begin{tabular}{|c|c|c|c|}
\hline \multicolumn{4}{|c|}{$\begin{array}{c}\text { Chart 2. Anti-Bullying Laws: Province Summary (The provinces marked with an asterisk }(*) \\
\text { require schools have a procedure in place for students to report bullying) (Anti-Bullying } \\
\text { Laws: Province Summary, 2017, p.2) }\end{array}$} \\
\hline Province & Summary & Province & Summary \\
\hline Alberta & $\begin{array}{l}\text { Bullying is defined under } \\
\text { The Education Act, and all } \\
\text { school boards are required } \\
\text { to provide and implement a } \\
\text { code of conduct. Private } \\
\text { schools are included under } \\
\text { The School Act. }\end{array}$ & British Columbia & $\begin{array}{l}\text { No anti-bullying law in } \\
\text { place. }\end{array}$ \\
\hline Manitoba & $\begin{array}{l}\text { All school boards of non- } \\
\text { religious and publicly } \\
\text { funded schools must } \\
\text { develop policies that } \\
\text { maintain respect for human } \\
\text { diversity. }\end{array}$ & New Brunswick & $\begin{array}{l}\text { There is an emphasis on } \\
\text { taking action, reporting, } \\
\text { investigating and } \\
\text { prevention of bullying } \\
\text { and cyberbullying. } \\
\text { Protocols for reporting } \\
\text { bullying } \\
\text { cyberbullying and } \\
\text { mandated. are }\end{array}$ \\
\hline $\begin{array}{l}\text { Newfoundl } \\
\text { and \& } \\
\text { Labrador }\end{array}$ & $\begin{array}{l}\text { The government in } \\
\text { Newfoundland and } \\
\text { Labrador provides a Safe } \\
\text { and Caring Schools Policy } \\
\text { to promote respect and } \\
\text { support among teachers, } \\
\text { students, parents and the } \\
\text { community. }\end{array}$ & $\begin{array}{l}\text { Northwest } \\
\text { Territories }\end{array}$ & $\begin{array}{l}\text { Bullying and electronic } \\
\text { bullying is defined. All } \\
\text { Divisional Education } \\
\text { Councils or District } \\
\text { Education Authorities } \\
\text { must ensure that schools } \\
\text { develop safe school } \\
\text { policies. }\end{array}$ \\
\hline $\begin{array}{l}\text { Nova } \\
\text { Scotia* }\end{array}$ & $\begin{array}{l}\text { Bullying and cyberbullying } \\
\text { is defined and addressed in } \\
\text { Nova Scotia's Education } \\
\text { Act. School administration } \\
\text { is responsible for } \\
\text { investigating any reported } \\
\text { incident. }\end{array}$ & Nunavut & $\begin{array}{l}\text { No anti-bullying law in } \\
\text { place. }\end{array}$ \\
\hline
\end{tabular}




\begin{tabular}{|c|c|c|c|}
\hline Ontario* & $\begin{array}{l}\text { The Ministry is expected to } \\
\text { develop a model bullying } \\
\text { prevention procedure to } \\
\text { assist individual school } \\
\text { boards in establishing their } \\
\text { own bullying prevention } \\
\text { procedures. }\end{array}$ & Edward & $\begin{array}{l}\text { No anti-bullying law in } \\
\text { place. }\end{array}$ \\
\hline Quebec* & $\begin{array}{l}\text { School administration is } \\
\text { responsible for } \\
\text { implementing anti-bullying } \\
\text { and anti-violence } \\
\text { procedures, and } \\
\text { maintaining reporting } \\
\text { systems throughout the } \\
\text { school year. }\end{array}$ & Saskatchewan & $\begin{array}{l}\text { No anti-bullying law in } \\
\text { place. }\end{array}$ \\
\hline $\begin{array}{l}\text { Yukon } \\
\text { Territory }\end{array}$ & $\begin{array}{l}\text { School administrators, in } \\
\text { consultation with their } \\
\text { school communities, are } \\
\text { responsible for developing } \\
\text { a school-based policy that } \\
\text { includes practices dealing } \\
\text { with bullying and } \\
\text { harassment. }\end{array}$ & & \\
\hline
\end{tabular}

Each province and territory defines bullying differently and all have their own legislation or policies to address. What is general for all is that educators are responsible for helping nurture and develop the social and emotional skills students need to engage in healthy relationships, and to teach students that bullying is wrong and unacceptable. In order to do this, there are certain responsibilities and expectations educators must fulfill, both in the classroom and at the ministry level. Bullying is a relational problem that impacts the social climate of a school community. The law can provide clear definitions of bullying behaviour, mandate the need for policies, assign responsibility and empower educators with disciplinary tools.

Both Canadian and international research stress the need for a whole school approach to bullying which includes the adoption of an anti-bullying policy and antibullying initiatives. A whole school approach has not been widely implemented in Canada. Although Canada is currently lacking a national model for needs assessments for bullying problems, the Canadian Public Health Association created an inventory of school safety surveys for students, teachers, parents, and administrators to be used as common measures of bullying in schools across the country. But there are a limited number of bullying statistics available to the Canadian public and they are provided by both government and non-government bodies.

Some provisions of the Accepting School Act, 2012 may help to improve students' confidence that the bullying they report will be dealt with, including a more precise definition of bullying, the legislated requirement for teachers to report suspected bullying and the principal's obligation to investigate. Specifically, the Act legislates: mandatory reporting by teachers and administrators of all aspects of bullying, including homophobic bullying; mandatory training of all staff in allying prevention and intervention; mandatory allowances of Gay-Straight Alliances in all 
secondary public and Catholic schools; and mandatory surveys every two years to be conducted in each school board by students and teachers to catch any discrepancies.

There is no gray area in the school environment. If a child reports bullying, or a teacher suspects bullying, the teacher has to report it and the principal has to investigate. It is much like the requirement report suspected child abuse. The logical consequence of having to report and follow up on bullying in a more systemic way is that administrators will get better at handling it. Improving school climate and staffstudent relationships and trust are also the key to creating an atmosphere where peer bystanders feel safer about reporting bullying to adults. Once the investigation of a reported bullying incident has established that bullying has indeed taken place, one of the keys to successful intervention is working with the parents of both the bully and the victim. Given the media coverage of catastrophic impacts experienced by some victims of bullying, it is very difficult for some parents to accept that their child is a perpetrator. The Act's clear definition of bullying helps to explain the difference between bullying and conflict of parents of victims (and also to staff and other students). Sometimes parents believe their child is the victim of bullying, but really it is a case of conflict.

Another interesting approach to intervening in bullying, currently used in schools of Canada, is to have teachers model effective intervention in bullying. In the past, teachers who observed bullying would pull the instigator aside for a private talk. Now it is done publicly, so that other students hear what we are saying and can learn from it. The staff found this hard to do at first, but teachers must be trained in how to take those public conversations. As Canadian educators confirm, they don't have data bullying yet, but they know that their suspension rates and absenteeism are lower, and at their Safe School Committee meeting they talk about what a better feeling there is in their building.

As many as $20 \%$ of all children attending school are afraid through much of the school day. Some of these children avoid lunch, recess, and the bathrooms out of fear that they will be humiliated or picked on by bullies. These are not children who are teased occasionally or who sometimes get into fights with their peers. These are children who are targeted over and over again. They cannot defend themselves against stronger, more powerful peers. This power imbalance is the essence of bullying.

\section{How to Help: Steps to Bully-Proof Your Child}

1. Confident children are less likely to become victims. Teach your child how to use «self-talk», which is a silent pep talk one can use when feeling picked on. The child should select something good about him- or herself and think about that during difficult moments.

2. There is strength in numbers. Tell your child to walk down the hall, into the lunchroom, or out to recess with others. Bullies will quickly target a child who is alone. Your child should stay near others even if they are not close friends. Better yet, your child should make close friends and the children should protect one another.

3. Skills for making friends include how to share, compromise, change the topic to avoid conflict, apologise when appropriate, and use a diplomatic approach.

4. Problem-solve difficult social situations and practise diplomatic responses during the dinner hour. Something that has been practised is easier to use when a difficult moment arises. Social skill groups are available in many schools today and books for both parents and children can be found in local libraries and bookstores. 
5. A submissive or victim stance may attract bullies. Your child should not have an intimidated, slouched appearance. Encourage your child to stand up straight and hold his or her head high. If a bully approaches, your child shouldn't freeze. It is best to walk away and join a group of children.

The common elements of legislation in Canada include the responsibilities of school boards to enact codes of conduct, anti-bullying policies, awareness campaigns, bullying response policies and the empowering of teachers and principals to use suspensions and exclusions.

Conclusions and prospects for further research. Bullying happens at all ages, in all countries, between children, teenagers and grown-ups. It happens mostly between the ages of 10-14. No form of bullying should be tolerated. Bullying in schools must be dealt with as a serious issue; it is not a normal behaviour and it can bring serious damage to the further development of the individuals being aggressed.

Overall, support from all levels is needed to help children and youth who bully to understand the implications of their behaviour, the importance of interacting respectfully with others and to find ways of achieving power and status through positive leadership. It is also clear that children who are bullied need protection from bullying and support in developing confidence and positive relationships.

As a good bullying prevention approach, the whole-school method can be applied in all types of communities including high risk communities. Successful whole school anti-bullying approaches are premised on the notion that bullying behaviour can be identified and redirected into a more prosocial direction through a systematic restructuring of the school's social environment.

Bullying will not disappear, but it can be controlled if people start to work together and decide to work on the entire system around the children. Stopping bullying requires commitment of everybody involved. Studies have shown that a higher percentage of children engaged in bullying behaviour is in middle school and high school than in elementary school. But, the percentages of children victimized gradually decreases with age.

\section{REFERENCES:}

Anti-bullying Laws in Canada. Lawyer \& Law Firm Edmonton, 16 July, 2018. [online] URL: Retrieved on February 12, 2019 from https://prowsechowne.com/antibullying-laws-in-canada/

Anti-Bullying Laws: Province Summary. Canada: Anti-Bullying Laws and Policies. - Alert Solutions : A Rave Mobile Safety Company. October, 2017. p. 2. [online] URL: Retrieved on February 13, 2019 from https://www.alertsolutions.com/AS/ SchoolAnnouncement/School_Announcement_Anti_Bullying_Laws_Canada.pdf

An Overview of Anti-bullying Legislation and Alternatives in Canada. Provincial laws on bullying in Canada. 1.07.2013. pp. 2-3. [online] URL: Retrieved on February 20, 2019 from https://www.lawnow.org/an-overview-of-anti-bullying-legislation-andalternatives-in-canada/

Bernstein, J. Y. \& Watson, M.W. (1997) Children Who are Targets of Bullying : A victim pattern Journal of Interpersonal Violence. Vol. 12. pp. 483-498.

Bullying \& Cyberbullying. Royal Canadian Mounted Police. 21.09.2017. p. 2. [online] URL: Retrieved on February 20, 2019 from http://www.rcmp-grc.gc.ca/cycpcpcj/bull-inti/index-eng.htm

Bullying Policy \& Legislation. PREVNet - Canada's Authority on Bullying. [online] URL: Retrieved on February 20, 2019 from https://www.prevnet.ca/resources/policy-and-legislation 
Bullying prevention in schools. Department of Public Safety and Emergency Preparedness [CA]. 31.01.2018. [online] URL: Retrieved on February 20, 2019 from https://www.publicsafety.gc.ca/cnt/rsrcs/pblctns/bllng-prvntn-schls/index-en.aspx

Bullying in Schools : Guidelines for Intervention and Prevention. Promoting Relationships and Eliminating Violence Network. 2007. 36 p. [online] URL: Retrieved on February 20, 2019 from https://cemh.lbpsb.qc.ca/educators/bullyingprevnet.pdf

Burger, C., Strohmeier, D., Sprober N., Bauman Sh. \& Rigby K. (2015) How Teachers Respond to School Bullying : An examination of self-reported intervention strategy use moderator effects, and concurrent use of multiple strategies. Teaching and Teacher Education. Vol. 51, pp. 191-202.

Bystanders Eyes on Bullying. [online] URL: Retrieved on February 20, 2019 from http://eyesonbullying.org/bystander.html

Craig, W.M. \& Pepler D. (1997). Observations of Bullying and Victimization in the School Yard. Canadian Journal of School Psychology. Vol. 13 (2), pp. 41-60.

Carach, A., Pepler D. \& Ziegler S. Bullying at School. A Canadian Perspective. Education Canada. Spring, 2005, pp. 12-18.

Eye on Bullying Toolkit. [online] URL: Retrieved on February 20, 2019 from http://eyesonbullying.org/bystander.html

Farrington, D. (1993) Understanding and Preventing Bullying. - In M. Torry (ed.), Crime and Justice. Vol. 17, pp.381-458.

Goldsmid, S. \& Howie, P. (2014). Bullying by Definition : An examination of definitional components of bullying. Emotional and Behavioural Difficulties. Vol. 19 (2), pp. 210-225.

Juvonen, J. \& Graham, S. (2014). Bullying in Schools : The Power of Bullies and the Plight of Victims. Annual Review of Psychology. Vol. 65, pp. 159-185.

Olweus, D. (1978). Aggression in the Schools : Bullies and Whipping Boys. Washington and London: Hallsted Press. 218 p.

Olweus, D. (2003). Bullying Prevention Program. [online] URL: Retrieved on February 20, 2019 from https://olweus.sites.clemson.edu/

Olweus, D. (1993). Bullying at School: What We Know and What We Can Do. NY: Blackwell, 152 p.

Olweus, D. (1992). Bullying Among Schoolchildren: Intervention and Prevention. - In R. Peters, R. McMahon and V. Quinsey (eds.) Aggression and Violence Through the Life Span. Newsbury Park, CA: Sage Publications, pp. 100-125.

Provincial and Territorial Legislation : Cyberbullying and the Non-consensual Distribution of Intimate Images. 19.01.2017 [online] URL: Retrieved on February 20, 2019 from https://www.justice.gc.ca/eng/rp-pr/other-autre/cndii-cdncii/p3.html

Smith, P.K. \& Brain, P.F. (2000) Bullying at Schools: Lessons From Two Decades of Research. Aggressive Behaviour. Vol. 26 (1), pp.1-9.

Smith, P.K. School bullying. [online] URL: Retrieved on February 20, 2019 from https://www.scielo.gpeari.mctes.pt/pdf/spp/n71/n71a05.pdf

Steven, V., De Bourdeandhuij I., Van Oost P. (2000) Bullying in Flemish Schools : An Evaluation of Antibullying Intervention in Primary and Secondary Schools. British Journal of Educational Psychology. Vol. 70, pp. 195-210. 


\title{
БУЛЛІНГ ЧИ КОНФЛІКТ? СТРАТЕГІЇ ЗАПОБІГАННЯ БУЛІНГУ ТА ЙОГО ПРИПИНЕННЯ У КАНАДСЬКИХ ШКОЛАХ
}

\author{
Федоришин Олександр \\ кандидат педагогічних наук, доцент, \\ доцент кафедри практики англійської мови \\ Рівненського державного гуманітарного університету, \\ м. Рівне, Україна \\ ORCID: 0000-0003-0731-0186 \\ e-mail: ofedoryshin@gmail.com
}

\begin{abstract}
Анотація. Стаття акцентує увагу на шкільному булінгу, який $є$ досить поширеним у різних країнах світу і вважається актуальною соціально-педагогічною i психологічною проблемою сьогодення. Як серйозне i масове явище булінг потребує вирішення, від чіткого визначення самого поняття до розробок практичних рекомендацій 3 його профілактики та протистояння. У статті представлені визначення і характеристика форм та видів прояву шкільного булінгу, які постійно змінюються, пристосовуючись до нових обставин; наприклад, поява такої нової сучасної форми агресії як кібербулінг. Зниженню рівня цього негативного соціального явища може слугувати досвід Канади щодо антибулінгових заходів. Питання булінгу є дуже актуальним у канадських школах. Школи Канади націлені на більш конструктивні принципи превентивного характеру до подолання i протистояння булінгу. Антибулінгова робота $є$ злагодженим механізмом і передбачає співпрацю школи з учнями та їх батьками, громадськими організаціями, членами громади і має підтримку державних інституцій.

Булінг не зникне сам по собі, але його можна взяти під контроль - за умови, якщо не буде байдужих і всі разом почнуть працювати, щоб захистити від нього дітей. Це має стати обов'язком кожного, хто задіяний у цьому процесі, - зупинити булінг. Дослідження показали, що таке негативне явище як цькування найчастіше спостерігається серед учнів середніх і старших класів, а його відсоток у початкових класах значно нижчий. Прояви булінгу зустрічаються у різному віці, у різних країнах між дітьми і підлітками. Вони наносять серйозну шкоду подальшому розвитку тих, хто відчув його на собі, і тому необхідна повна підтримка на всіх рівнях, щоб допомогти зрозуміти непристойність на неприпустимість такої поведінки і звернути увагу на важливість формування поваги у стосунках 3 іншими і вміння знаходити шляхи самоствердження через позитивне лідерство.
\end{abstract}

Ключові слова: шкільний булінг, кібербулінг, антибулінгові програми, агресія, превентивні заходи, протистояння булінгу.

Стаття надійшла до редакиії 17.04.2019 p. 